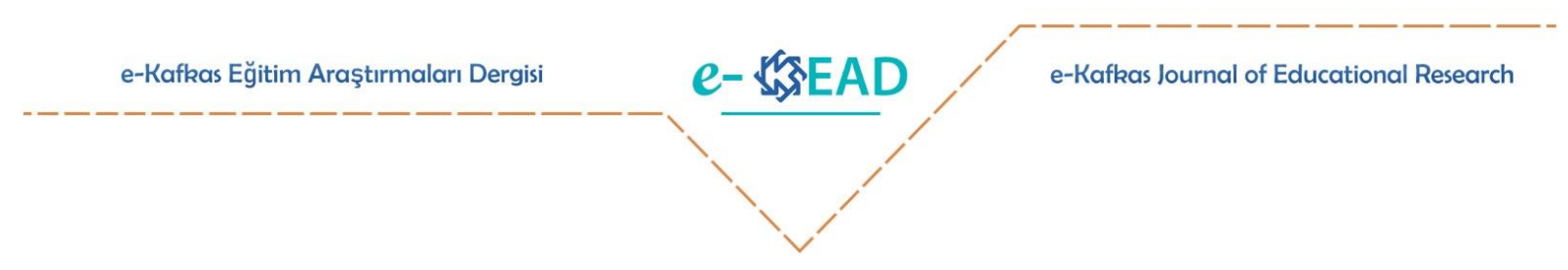

\title{
A Corpus Study on Topic Shifting Discourse Macro Markers in TED Talks
}

\author{
Hamideh Hamdi ${ }^{1}$ (D)
}

To cite this article: Hamdi, H. (2020). A corpus study on topic shifting discourse macro makers in TED talks. $e$ Kafkas Eğitim Araştırmaları Dergisi, 7, 229-239. doi: 10.30900 /kafkasegt.742904

Research article

Received:26.05.2020

Accepted: 24.08.2020

\section{$\ddot{O} z$}

Önemli sayıda öğrenci kendi ülkelerinin dışındaki üniversitelere kayıt olmaktadır. Kayıt yaptırılan bu üniversitelerin çoğunda dersler İngilizce öğretilmektedir ve bu durum ana dili İngilizce olmayan öğrenciler için zorlayıcı olabilir. Bu öğrencilerin akademik çalışmalarında başarılı olabilmeleri, dersleri takip edebilmeleri ve dersleri dinleyebilmeleri için dinleme becerisi uzerine eğitilmeleri gerekmektedir. Yabancı dil sınıflarında Ted konuşmaları üniversite derslerine benzeyen yapıdadır ve bu konuşmaların kolayca erişilebilen gerçek materyaller olmaları sebebiyle üniversitelerde öğrencileri gerçek hayata hazırlamak için kullanılabilir. Yabancı dilin İngilizce olduğu sınıflarda tanımlanması ve tanıtılması gereken söylem işaretçileri konuşmacının ne yapmak istediği fikrini kavrayabilmede dinleyicilere destek sağladığı ve akademik derslerde önemli bir rol oynadığı için hem üniversite derslerinde hem de Ted konuşmalarında geniş çapta kullanılır. Konuşmacılar tarafindan konuşmalarını düzenlemek ve dinleyicilerin onları takip etmelerine yardım etmek için ders söylevlerinde makro isaretçiler kullanılır. Konu değiştiren makro isaretçiler dinleyiciye konunun ve konuşmanın değiş̧eceği sinyalini verdikleri için son derece önemlidir. Bu çalışma Ted konuşmalarında konuları ya da alt konuları değiştirmek için kullanılan makro söylem işaretçilerini ortaya çıkarmayı amaçlamaktadır. Bu nedenle, konu değiştiren işaretçileri kaydetmek için 18 Ted konuşması el ile analiz edilmiştir. Sonrasında bulunan işaretçilerin sıklık derecesi ilgili derlemde kontrol edilmiştir. Araştırma sonucunda " $\mathrm{Bu}$ yüzden " ve " Şimdi " ifadeleri ile kullanılan duraklamaların, konuları ya da alt konuları değiştirmek için kullanılan en sık isaretçiler olduğu ortaya çıkmıştır.

Anahtar Sözcükler: Söylem işaretçileri, makro işaretçiler, konu değiştiren işaretçiler

\begin{abstract}
Many students enroll at universities in countries other than their own; in majority of these universities the courses are taught in English which might be challenging for those whose native language is different. These students need to be trained to be able to follow the lectures to be successful in their academic studies. In EFL classes TED Talks (Technology, Entertainment, Design), which is authentic materials can be used to prepare students to real life lectures at universities since they have a resembling structure to university lectures. In both university lectures and TED Talk speeches discourse markers are widely used that need to be identified and introduced in EFL classes since they play important roles in lectures, and assist listeners to get the idea what the speaker intends to do. Macro markers are used in lecture discourses by speakers to arrange their speeches and help the audience follow them. |Topic shifting macro markers are vital since they signal the listener that the topic and flow of the speech is going to change. This study aimed to find out what discourse macro markers were used in TED Talk speeches to change topics or subtopics. For this reason transcripted 18 speeches were analyzed to note down the topic shifting markers. A native speaker confirmed if the topics were changing or not. Later the frequency of the markers were checked on the related corpora. It was revealed that using pauses along with 'so' and 'now' were the most frequently used markers to shift the topics or subtopics.
\end{abstract}

Keywords: Discourse markers, macro markers, topic shifter

\footnotetext{
${ }^{1}$ hamideh.hamdi@gmail.com, Anadolu University
} 


\section{Introduction}

Discourse markers are defined as a class of verbal and non-verbal tools that provide contextual coordination for ongoing daily talks (Schiffrin, 1987). Apart from daily conversation, they can contribute to a better comprehension of lectures and speeches by signaling the arrangement of the ideas of the speaker. The importance of discourse markers can be highlighted if we consider the high number of non-native students doing their academic studies in a country other than their own. This fact has inspired researchers to conduct studies to show how discourse markers can decidedly facilitate the understanding of academic lectures for non-native students (Chaudron \& Richards, 1986; Rido, 2015). Chaudron \& Richard, (1986) argue that since academic lectures are the major mode of transferring the information at universities, seminars, and workshops, the lecturers should coherently present the ideas. To achieve coherence discourse markers are essential to help the audience to relate the utterances. As claimed by Chaudron \& Richard, (1986), besides having background knowledge of the topic of the lectures, the listeners can also benefit from the macro-structure and discourse organization of the lectures. TED Talks have been quite well-known and popular during the last decade and can be considered as authentic lectures given majorly by native speakers of different languages since the event takes place in different parts of the world. Caliendo \& Compagnone (2014), believe TED Talks can be compared to academic lectures since they cover various topics with a huge number of audiences. Uicheng \& Crabtree (2018) also claim that since TED speeches can be categorized at the same level with university lectures, it can be assumed that TED speakers use discourse markers to be able to convey messages as clearly as possible. Changing or shifting topics or subtopics is a discourse act that happens in all speeches and the speakers need to signal this shift therefore their audience is able to follow the speech. This study aims to find out which discourse markers are used by presenters to signal topic or subtopic shifts in TED Talk speeches.

\section{Definition of Discourse Markers}

The study of DMs has been popularized since the 1970s and 80s (Ranger, 2018, p.3). However, considering their being controversial, defining discourse markers is not an easy task to do; we can see this fact if we notice that Brinton (1996) and Fraser (2009) have listed approximately thirty-nine terms while referring to DMs (Ranger, 2018). Fraser (2009), identifies DMs as a subcategory of pragmatic markers that "signal a relationship between the discourse segment which hosts them, and the prior discourse segment" (p.296). Harmer (2007) believes Discourse markers are an essential part of an understanding of spoken utterances and states that discourse markers can be used for buying time, taking turns, or marking the start or end of an utterance by using grammar and vocabulary. According to Rowling (2002), discourse markers are lexical items used to show the discourse plan of the speaker, and Schiffrin, (1987) defines them as verbal or non-verbal tools that are used for various functions. The definition that highly suits the purpose of the current study is by Hyland (1999), who argues that considering the communication between experts and non-experts, discourse markers can ease the receiving of the information which leads to improvement of understanding. This last definition is very close to what Chaudron \& Richard, (1986) claim that discourse markers can assist the students to comprehend the conveyed and desired message by the lecturer in academic contexts.

\section{Academic Lectures}

Lecturing is a commonly used method of delivering information in academic contexts, and researchers have identified different styles of lecturing. Researchers have classified lectures in variously throughout the years, for example, Morrison (as cited in Fortuño, \& Gómez, 2005) identifies two classes of lectures: 1) Formal and 2) Informal; the formal lectures are defined as 'close spoken prose', whereas the informal one has 'high informational content' which is not expressed too formally. Goffman (1981) claims that lectures have three styles: 1) memorization, 2) aloud reading, and 3) fresh talk. Dudley-Evans and Johns (1981), on the other hand, classify them differently, they claim there are three types of lectures: a reading style, a conversational style, and a rhetorical style, and categorize each type of the lecture according to the way the lecturer presents it:

- Reading Style: the lecture is read through notes. 
- Conversational Style: The lecturer has planned about the topic but the speech is informal and not planned and interaction happens.

- Rhetorical Style: The lecturer acts as a performer for example they try to make jokes.

Lectures have also been classified by the taxonomy of 'interactive' and 'non-interactive' styles, with the former motivating participants to join the lecture (Northcott 2001), while in the latter, the lecturer or the instructor has the whole control (Morell 2004). These classifications reflect the fact that academic lectures have intrigued many researchers to study their language as a spoken discourse (Flowerdew, 1994; MacDonald, Richard, \& White, 2000; Morell, 2004). The question of how lecturers organize their speech to convey their messages more efficiently has been the trigger of studies that have focused on the discourse markers used in lectures.

\section{Macro and Micro Discourse Markers in lectures}

Macro markers are how academic lecturers try to mark what they are going to present (Chaudron and Richards, 1986), for example: "Okay, let's get started", at the onset of a lecture, and "now here/we'll put up our last slide/and come to the conclusions" at the end of it (Flowerdew, \& Miller, 1997; p.38). The use of Macro markers helps the lecturer to keep the listeners involved, furthermore, they can assist the listeners in linking the flow of the lecture to other parts of the speech. According to Flowerdew, \& Miller, (1997), macro markers can also link the speech to their previous knowledge, for example:

"remember/er last time/a long time ago/er before the New Year//I stressed to you/ah/how dramatic the change had been//how dramatic the change has been in our region" (p.39).

It is argued that Macro discourse markers function by catching attention to the most important information of the lectures. Sadeghi \& Heydaryan (2012) refer to macro discourse markers as "signals or meta-statements about the major propositions" (p.167). On the other hand, Micro markers are defined as the links between sentences that can also be referred to as fillers such as 'well', 'so', 'now', 'you know'. These latter markers come with the information of the text that is at the lower level which is also utilized by listeners to gain more time to process different parts of the discourse. Chaudron and Richards (1986) also claim that the macro makers point to important shifts in the lecture while the micro markers connect the sentences. DeCarrico and Nattinger (1988) refer to macro organizers as "topic-markers, topic-shifters, summarizers, amplifiers, relators, evaluators, qualifiers in lectures (p. 185). Uicheng \& Crabtree (2018; p.5), list examples for Micro and Macro discourse markers as follows:

Table 1

Examples for Micro Marker by Uicheng \& Crabtree (2018)

\begin{tabular}{ll}
\hline Temporal link & then, and, now, after this, at that time \\
\hline Causal Link & because, so \\
\hline Contrastive Relationship & but, actually \\
\hline Relative Emphasis & you see, unbelievably, of course \\
\hline Framing/Segmentation & well, ok, alright? \\
\hline
\end{tabular}

Table 2

Examples for Macro Marker by Uicheng \& Crabtree (2018)

To begin with, what we've come to by now

Macro Discourse Markers was that, let's go back to the beginning, What I'm going to talk about today, That/this is why, and As you may have heard.

Moll (2000) studied discourse markers in two kinds of lectures: interactive and noninteractive. For this purpose, she utilized Chaudron and Richards' (1986) micro and macro markers classification but she modified the category of micro markers. For both interactive and non-interactive lectures she has defined six subcategories for each as follows: 
Table 3

Non-Interactive Micro Markers by Moll (2000)

\begin{tabular}{llllll}
\hline Segmentation & Temporal & Causal & Contrast & Emphasis & Elicitation \\
\hline Ok, and, or, & And then, & So, that & But, & In fact, of & Ready? \\
now, well & After that & means, & Although & course, & \\
& & such as, & \\
& & note & \\
& means, & & \\
because, & & \\
& so (that), & & \\
& & & & \\
& & & & \\
& &
\end{tabular}

Table 4

Interactive Micro Markers by Moll (2000)

\begin{tabular}{llllll}
\hline Segmentation & Temporal & Causal & Contrast & Emphasis & Elicitation \\
\hline $\begin{array}{l}\text { Ok, and, or, } \\
\text { now, anyway }\end{array}$ & Then & So & But, & Of course, & Anything else? \\
& & & Unless & as you & $\begin{array}{l}\text { What? Why } \\
\text { know } \\
\end{array}$ \\
& & & & $\begin{array}{l}\text { not Louder } \\
\text { please }\end{array}$ \\
\hline
\end{tabular}

Table 5

Non-Interactive Macro Markers by Moll (2000)

\begin{tabular}{llllll}
\hline Starter & Elicitation & Accept & Attitudinal & Meta statement & Conclusion \\
\hline $\begin{array}{l}\text { Today I'm } \\
\text { going to talk }\end{array}$ & What do we & - & I would dare & I have a quote & What you \\
about...To & Remember... & - & to say... & for you... & have seen \\
begin...The & Any believe & I'd like to read & in this lecture \\
reasons... & questions... & & $\begin{array}{l}\text { that... } \\
\text { I wouldn't } \\
\text { doubt it. }\end{array}$ & this to you... & first was... \\
\hline
\end{tabular}

Table 6

Interactive Macro Markers by Moll (2000)

\begin{tabular}{llllll}
\hline Starter & Elicitation & Accept & Attitudinal & Meta statement & Conclusion \\
\hline $\begin{array}{l}\text { We are going to } \\
\text { get started }\end{array}$ & $\begin{array}{l}\text { I have a } \\
\text { question }\end{array}$ & $\begin{array}{l}\text { That's } \\
\text { right. }\end{array}$ & $\begin{array}{l}\text { I think... } \\
\text { It's a }\end{array}$ & $\begin{array}{l}\text { To back up } \\
\text { that statement }\end{array}$ & To finish \\
Can I have your & for you. & That' & difficult & & lecture, \\
attention? & $\begin{array}{l}\text { Do you } \\
\text { think..? }\end{array}$ & & question to & & We'll \\
$\begin{array}{l}\text { We will } \\
\text { begin now }\end{array}$ & $\begin{array}{l}\text { answer. } \\
\text { Do you }\end{array}$ & & & & continue \\
& agree..? & & & & with this \\
& & & & tomorrow \\
\hline
\end{tabular}

Young (1994) also has investigated the use of Macro and Micro markers in university lectures. The data were collected by recording university lectures to both natives and non-natives. She uses the term of 'phase' to describe Macro markers and reports six phases in university lecture discourses: Discourse Structuring Phase, Conclusion phase, Evaluation phase, Interaction phase, Content phase, and Example phase. She believes phrase structures that mark the beginning, middle, and end of a lecture, are more helpful than Macro markers to understand lectures. Belles (2004) conducted a study in which American and British lecture corpora were contrasted regarding their micro and macro markers. The results revealed that although segmentation, causal, and contrast subcategories were similar, the frequency of segmentation in American corpora was two times more than that of the British. Concerning the macro markers, it was found out that Meta statement, attitudinal, and starters were the most frequently used in both of the corpora. DeCarrico and Nattinger (1988) argue that academic speeches are performative and by analyzing them, formulaic phrases can be found in abundance which directs the listener into where that lecture is heading to. Chaudron and Richards (1986) refer to these phrases as macro markers, which are indicative of the information that the lecturer will give following them, such as giving examples or retelling the same proposition 
differently. They also claim that macro markers are better assistants in recalling the text rather than micro markers.

\section{Topic-Shifters}

Mullany \& Stockwell (2010) claim that during conversations the partners change the topics while they are progressing the conversation, whereas in formal cases topics are planned, where a new topic is introduced following a transitional phase. Chafe (2008) argues that "A topic is defined as a coherent organization of thoughts introduced by a participant in a conversation and developed either by that participant or another or by several participants together" (p.674). It is important to note that studying topic boundaries might be challenging since they can have a noticeable beginning, but the ending might not be as clear. The shift from one topic to the other may be cued phonetically like a pause (Schiffrin, 2008). Another reason that makes it demanding to study topic shifting is that there are many ways to divide a talk or speech into smaller segments (Purver, 2011); and as Fraser (1998, p.29) mentions shift of the topics is not always explicit and clear such as 'before I forget, on a different note'. All these various points show that studying topic shifts needs a lot of researches to be understood; what is more is, before studying topics changes, a researcher has to be clear if they are looking for 'sentence topic', 'utterance topic', or 'discourse topic'. DeCarrico and Nattinger (1988) list different examples of topic shifters in three types of lectures:

Table 7

Topic Shifting Macro Markers by DeCarrico and Nattinger (1988)

$\begin{array}{ll} & \text { So let's turn to. } \\ \text { Let me go to } & \\ \text { Conversational Style } & \text { On to }\end{array}$

Topic Shifter

Let's look at...

One final point/thing is...

I'd like to talk about

Back to

Lots more to talk about, but on to.

All right Now (falling intonation + pause)

OK (falling intonation + pause)

\begin{tabular}{|c|c|}
\hline Rhetorical Style & $\begin{array}{l}\text { Let me talk a little bit about } \\
\text { This leads to... } \\
\text { The (other) thing that } \mathrm{X} \text { is } \mathrm{Y}\end{array}$ \\
\hline Reading Style & $\begin{array}{l}\text { Now I'd like to give you .... } \\
\text { Any other comments before I turn to ...? } \\
\text { End of quote } \\
\text { As to what is... }\end{array}$ \\
\hline
\end{tabular}

Researchers have identified other discourse markers that act as topic shifter too, for example, the discourse markers "so" has been known to have various functions of showing 'result', 'inference', and 'action' (Schiffrin. 1987). However, it was found out by Howe (1991) that 'so' can be indicative of topic initials. Studies by Johnson (2002) and Bolden (2006) report that 'so' can be used to change topics in conversations, the same was reported on discourse marker "now" in a study by Heeman, Byron \& Allen, (1998). Mullany \& Stockwell (2010) also note the use of 'okay' followed by a short 'pause' as the marker of a new topic or subtopic, they argue that it could also happen by using a "lengthy pause or a hesitation err" (p. 86).

\section{TED Talks}

As a non-profit organization, TED holds conferences in various parts of the world. Numerous speakers deliver short speeches on different topics. TED speeches are also available online, and people can watch them either on YouTube or TED Website. The videos are quite popular and millions of people watch them every day. TED organization also has many numbers of translators who translate the videos into their native language. Caliendo and Compagnone (2014), identify TED speeches very close to university lectures, regarding their discourse. This is the reason TED Talks have been the subject of various studies. According to Chris Anderson, the head of TED Talk, TED speakers have to be clear and convey the message to the listeners as clearly as possible. Tsai (2015) investigated the 
speakers' prosodic voice characteristics; the purpose of the study was to compare TED speakers with other public speakers, he found out that, TED Talks were denser, due to their shortness regarding time limits. He also argues that lectures tend to have more speech pauses than TED speeches. Uicheng (2018) claims that the urge of being clear highlights the importance of discourse markers to indicate the lecturer's ideas and beliefs. Bonami and Hofherr (2004), argue that discourse markers are used in conversational speech more than any other form of communication. Considering the categorization of academic speeches by Dudley-Evans and Johns (1981), TED Talks can be classified as Conversational speeches, and this study is going to analyze TED Talks in English considering the use of Topic Shifting Macro markers.

\section{Statement of the problem}

The increasing number of exchange students as well as Erasmus students who study at the universities abroad, highlights the importance and necessity of academic lecture comprehension, for this reason, there are many studies on various aspects of academic lectures. TED speeches are widely used in EFL classrooms by teachers to make their students ready for those lectures. However, there are not as many studies on TED speeches as academic lectures. I believe Topic shifting discourse markers also demand more studies, considering the fact that they can be vague and surprisingly various, what is more, topic shifting macro DMs have important roles in understanding and following the flow of the talks; these are the reasons this study focuses on Topic shifting macro markers and it tries to investigate the frequency and type of the topic shifters in TED speeches. The related research question of this study is:

1. Which macro-discourse markers are most frequently used to signal a shift in topics, in TED Talk speeches?

2. Which of the Topic Shifting Macro markers listed in DeCarrico and Nattinger (1988), regarding conversational speeches, are used more frequently in TED Talk speeches?

\section{Methodology}

The purpose of this study is to investigate the type and frequency of topic shifting macro markers in TED Talk speeches, and two sets of data were collected for this study. One set was collected by using the official TED site videos. The second set of the data came from TCSE, or the TED Corpus Search Engine, which has been developed by Yoichiro Hasebe and has 3,166 TED transcripts.

\section{Data Collection}

As mentioned above, two sets of data were collected for this study. One set was collected by using the official TED site videos; eighteen videos were chosen from six popular topics of TED Talk, and the time length of the speeches was set on 12 to 18 minutes. Three speeches were chosen from each topic of technology, entertainment, design, business, science, and global issues. The selected speeches were given during the last two years. The transcripts of the speeches were printed and analyzed manually to find out how the speakers change the related topics in their speeches the analysis of the data were double-checked by a native speaker to assure that the topic of the utterances was changed and DeCarrico and Nattinger (1988) classification of topic shifters for conversational speeches was used as hints. The second set of the data came from TCSE, or the TED Corpus Search Engine, which has been developed by Yoichiro Hasebe. The website includes 3,166 TED transcripts which were searched to find out the frequency that the speakers use the topic shifting macro markers that were found by the first set of data and the markers that DeCarrico and Nattinger (1988) have listed for conversational speeches. For this purpose, the listed macro markers were searched at https://yohasebe.com/tcse. One advantage of this website is the chance it gives researchers to choose the discourse marker option. When ticked the site highlights the words that have been used as discourse markers. For example to search for the discourse marker "so" the command of " searched for, where "^" shows the sentence initials only, and by ticking the option of "discourse marker", wherever "so" has been used as a discourse marker gets highlighted. The same procedure was done for all of the markers listed in DeCarrico and Nattinger (1988) and those found from transcriptions manually. 


\section{Findings}

This study aims to find out which discourse macro markers are used in TED speeches; therefore; transcriptions of eighteen TED speeches were analyzed manually and the findings are reported in this section.

\section{Which discourse macro- markers are used to signal a shift in topics in TED Talk presentations?}

After manually analyzing the eighteen speeches on different topics the found markers are shown in the table below.

Table 8

The Discourse Macro Markers Found in Eighteen TED Speeches

\begin{tabular}{|c|c|}
\hline Title of the speech & Macro markers used for shifting topics \\
\hline $\begin{array}{l}\text { What we're getting wrong in the fight to } \\
\text { end hunger }\end{array}$ & $\begin{array}{l}\text { 1. }\{\text { pause }\}+\text { time setting 2. }\{\text { pause }\}+\text { location } \\
\text { setting } 3 \text {. 'So' }\end{array}$ \\
\hline $\begin{array}{l}\text { A video game that helps us understand } \\
\text { loneliness }\end{array}$ & $\begin{array}{l}\text { 1. }\{\text { pause }\}+\text { so } 2 . \quad\{\text { pause }\}+o k+\{\text { pause }\} 3 . \\
\{\text { pause } 4 .\{\text { pause }\}+\text { rising intonation }\end{array}$ \\
\hline $\begin{array}{l}\text { The transformative power of video } \\
\text { games }\end{array}$ & $\begin{array}{l}\text { 1. \{pause\}+ so 2. "now" 3. "Let's take a } \\
\text { moment to" 4. "so I kind of want to end with }\end{array}$ \\
\hline Why talent carries you further than fame & 1. $\{$ pause $\}+$ so 2. pause\} 3. $\{$ pause $\}+$ "now" 4. \\
\hline $\begin{array}{l}\text { My identity is a superpower - not an } \\
\text { obstacle }\end{array}$ & 1. \{pause\} 2. "anyway" \\
\hline $\begin{array}{l}\text { Why women should tell the stories of } \\
\text { humanity }\end{array}$ & $\begin{array}{l}\text { 1. }\{\text { pause }\}+\text { rising intonation } 2 \text {. }\{\text { pause }\}+\text { so } 3 \text {. } \\
\text { "now' 4. "let me talk about" } 5 \text {. }\end{array}$ \\
\hline $\begin{array}{l}\text { Stunning buildings made from raw, } \\
\text { imperfect materials }\end{array}$ & 1. "now" 2. "so" 3. "now I am going to" \\
\hline $\begin{array}{l}\text { The importance of diversity in the comic } \\
\text { book universe }\end{array}$ & $\begin{array}{l}\text { 1. "now" 2. "so" 3. "so, let's talk about" } 4 . \\
\text { "now, I am going to" }\end{array}$ \\
\hline $\begin{array}{l}\text { How urban spaces can preserve history } \\
\text { and build community }\end{array}$ & $\begin{array}{l}\text { 1. "now" 2. "I'd like to share" 3. "so" 4. " a little } \\
\text { quick story here" } 5 \text {. }\end{array}$ \\
\hline A radical plan to end plastic waste & 1. "now" 2. "so" 3. “ok" \\
\hline $\begin{array}{l}\text { The human skills we need in an } \\
\text { unpredictable world }\end{array}$ & 1. "now" 2. "so" 3. \{pause\} \\
\hline $\begin{array}{l}\text { How to break bad management habits } \\
\text { before they reach the next generation of } \\
\text { leaders }\end{array}$ & 1. I want to talk about 2. "so" 3. \{pause\} \\
\hline $\begin{array}{l}\text { What happens in your brain when you } \\
\text { taste food }\end{array}$ & 1. "now" 2. "so" 3. \{pause\} 4. "let's.." \\
\hline $\begin{array}{l}\text { A climate change solution that's right } \\
\text { under our feet }\end{array}$ & 1. "so" 2 \\
\hline $\begin{array}{l}\text { The real relationship between your age } \\
\text { and your chance of success }\end{array}$ & $\begin{array}{l}\text { 1. "now" 2. "so" 3. \{pause\} 4. "so, let's } \\
\text { go back to" 5. "so let's look at" } 6 \text {. "so the } \\
\text { question is.." }\end{array}$ \\
\hline $\begin{array}{l}\text { How we can protect truth in the age of } \\
\text { misinformation }\end{array}$ & 1. "now" 2. "so" 3. \{pause\} \\
\hline $\begin{array}{l}\text { Where in the world is it easiest to get } \\
\text { rich? }\end{array}$ & 1.“so" 2. "let's look at" \\
\hline $\begin{array}{l}\text { How will we survive when the } \\
\text { population hits } 10 \text { billion? }\end{array}$ & 1. "now" 2. "so" \\
\hline
\end{tabular}

As we see, the use of "so", "now", "Let's..." and the use of pauses are very common in the selected speeches:

"I believe that technology and innovation have the power to solve real problems, especially hunger/ \{pause\}/So/ in 2017 I created an app that would inventory everything that a business sells 
and make it super easy for them to donate this excess food that would typically go to waste at the end of the night."

As we see in the extract above the speaker changes the topic from the use of technology to stop hunger with a short pause and follows that with "so", or in the speech about a video game about loneliness, the speaker uses "ok" to mark that they will be switching the topic:

"And I know a lot of us are guilty of this, because it's an easy way to not think about your own issues. Isn't it? Hmm? Hmm? Hmm? OK, the turning point came when I fell into an emotionally abusive relationship just a few years ago."

As we see the speakers preferred using very short intervals to show topic shifting. However, there were a few cases that attempted to mark the shifting more explicitly as:

"When should that appear?/So let's go back to the party spoiler/ and ask ourselves: Why did Einstein make this ridiculous statement, that only before 30 you could actually be creative?"

Which of the Topic Shifting Macro markers listed in DeCarrico and Nattinger (1988), regarding conversational speeches, are used in TED Talk speeches?

To answer this question the TCSE developed by Yoichiro Hasebe was used which consists of 3,166 TED transcripts. The frequency of topic shifting macro markers listed on DeCarrico and Nattinger (1988) and the markers found in the previous section for conversational speeches are as follows:

Table 9.

The Frequency of Macro Markers Used in TED Talk Speeches.

\begin{tabular}{llll}
\hline $\begin{array}{l}\text { Macro Marker Proposed by } \\
\text { DeCarrico and Nattinger (1998) }\end{array}$ & Frequency & $\begin{array}{l}\text { Macro Markers found } \\
\text { manually from TED } \\
\text { Talks }\end{array}$ & Frequecy \\
\hline OK & 771 & So & 36,576 \\
$\begin{array}{l}\text { So let's turn to } \\
\text { Let me go to }\end{array}$ & 6 & Let's take a moment & 6 \\
Mn to & 10 & I want to end with & 30 \\
Let's look at & 0 & anyway & 138 \\
One final point/thing is... & 301 & Let me talk about & 37 \\
I'd like to talk about & 4 & I'd like to share & 66 \\
Back to... & 8 & I want to talk about & 340 \\
Lot more to talk about, but on on & 62 & Let's go back to & 62 \\
to ... & 0 & Let's look at & 301 \\
All right & 47 & Now & \\
Now & 19,836 & & 19,836 \\
\hline
\end{tabular}

Therefore as it is obvious from the table the most frequent markers that have been used are "so", and "now". This finding is also matching with the finding of the manual analysis of the TED speeches.

\section{Discussion, Conclusion and Recommendations}

The current study aimed to find out which discourse macro markers were used commonly in TED Talk speeches to shift the topics or subtopics and then compare their frequency with the macro markers in conversational speeches proposed by DeCarrico and Nattinger (1988). To answer the first research question eighteen TED speeches from various topics were selected and their transcriptions were analyzed manually. The finding revealed that the most commonly used markers to shift a topic were "so", "now" and the use of "pause". This finding is in parallel with the studies that have reported 'so' and 'now' as discourse markers to shift topics (Bolden, 2006; Heeman et.al, 1998; Howe, 1991; Johnson, 2002). The speakers' preference to use one-word markers or even pauses also confirms Tsai (2015) concerning the density of TED speeches, in other words, due to the time limit that TED speakers have, they try to switch the topics as fast as possible. However, unlike what Tsai (2015) had mentioned that pauses are less frequent in TED speeches, it was found out that pauses are used frequently to change the subtopics and topics, which makes it challenging to notice the change of the 
topics. This finding can be an evidence for Schiffrin, (2008) claim that pauses can mark a topic shift, which in turn is against what Uicheng (2018) claims that TED speakers change topics in a clear way. TED speakers, during their speeches, need to give background information, introduce the main topic of the speech, and convey the message in a very limited time. This makes them jump from one subtopic to another in a vague way which quite understandable. To answer the second research question the macro markers for conversational speeches that mark the shift in the topics were searched for in TCSE a TED Talk Corpora platform created by Yoichiro Hasebe. Both the markers found in the manual analysis and the markers listed in DeCarrico and Nattinger (1988) were searched for. The results show that among the markers from DeCarrico and Nattinger (1988) It is 'now' followed by ' $\mathrm{OK}$ ' that are being used more frequently than others which again comes from the density of the speeches; moreover, as it is seen in table 2.1 there are other macro markers that were not in DeCarrico and Nattinger (1988). This finding confirms the claim of Purver (2011) on the variety of ways that speakers can segment their speeches.

\section{Conclusion and Suggestions}

This study focused on the use of discourse macro markers used in TED speeches and found out that despite the use of multi-word markers like "I'd like to talk about..", speakers tend to use oneword markers like "so", "now" and "ok" to change their topics, the various use of which is not highlighted neither in language books nor in the classrooms; for example, the students tend to use "now" mostly as an adverb while it can have an important function in the discourse as a topic changer. Furthermore, in many cases, the shift in the topic or subtopic was preceded by pauses. It can be inferred that TED speakers try to arrange their speeches in a limited time set, this also can be explained during students' listening activities to make them able and prepared to follow the topics in the lectures, since TED speeches are widely used in EFL classes to develop students' listening comprehension ability, teachers need to practice and introduce these markers to their learners. Topic shifting markers can also be used in speaking tasks of the students; in the course books very limited discourse markers are normally introduced to learners such as "anyway" and "by the way". However, EFL students need to know that they might confront with various markers in different contexts. It should be noted that the topic shifting discourse markers can be used not only in presentations but also in class discussions and the debates among students, therefore teachers need to observe their students' production and ensure that they apply them to sound more natural. 


\section{References}

Bellés-Fortuño, B. (2004). The spoken academic discourse of the social sciences. Discourse Markers within the university lecture genre. Unpublished MA Thesis. Castelló: Universitat Jaume I. Retrieved from http://hdl.handle.net/10803/10442

Bolden, G. B. (2006). Little words that matter: Discourse markers "so" and "oh" and the doing of other-attentiveness in social interaction. Journal of Communication, 56(4), 661-688. Retrieved from https://doi.org/10.1111/j.1460-2466.2006.00314.x

Bonami, O. \& Hofherr, P. C. (Eds.). (2004). Relational adjectives as properties of kinds. Empirical issues in formal syntax and semantics, 5, 179-196. Retrieved from https://repositori.upf.edu/bitstream/handle/10230/23161/mcnally_eiss5_rela.pdf?sequence=1

Brinton, L. J. (1996). Pragmatic Markers in English: Grammaticalization and Discourse Functions (Topics in English Linguistics 19). Berlin/New York: Mouton de Gruyter. Retrieved from https://books.google.com.tr/

Caliendo, G. \& Compagnone, A. (2014). Expressing epistemic stance in university lectures and TED talks: a contrastive corpus-based analysis. Lingue E Linguaggi, 11, 105-122. Doi:10.1285/i22390359v11p105

Chafe, W. (2008). The Analysis of Discourse Flow. In Schiffrin (Eds.), (pp. 673-687) The Handbook of Discourse Analysis. Blackwell Publishing.

Chaudron, C. \& Richards, J. C. (1986). The effect of discourse markers on the comprehension of lectures. Applied Linguistics, 7(2), 113-127. Doi:10.1093/applin/7.2.113

DeCarrico, J. \& Nattinger, J. R. (1988). Lexical phrases for the comprehension of academic lectures. English for specific purposes, 7(2), 91-102. Retrieved from https://doi.org/10.1016/0889-4906(88)90027-0

Deroey, K. \& Taverniers, M. (2011). A corpus-based study of lecture functions. Moderna park, 105(2), 1-22. Retrieved from http://ojs.ub.gu.se/ojs/index.php/modernasprak/article/view/793/827

Deroey, K. L., \& Taverniers, M. (2012). Just remember this: Lexicogrammatical relevance markers in lectures. English for Specific Purposes, 31(4), 221-233. Retrieved from https://doi.org/10.1016/j.esp.2012.05.001

Dudley-Evans, A. \& Johns, T. F. (1981). A team teaching approach to lecture comprehension for overseas students. The teaching of listening comprehension, 30-46. Retrieved from https://www.teachingenglish.org.uk/

Flowerdew. J (Ed.). (1994). Academic listening: research perspectives. Cambridge: Cambridge University Press.

Flowerdew, J., \& Miller, L. (1997). The teaching of academic listening comprehension and the question of authenticity. English for specific purposes, 16(1), 27-46. Retrieved from https://doi.org/10.1016/S0889-4906(96)00030-0

Fortuño, B. B. \& Gómez, I. F. (2005). Spoken academic discourse: An approach to research on lectures. Revista española de lingüística aplicada, (1), 161-178. Retrieved from https://dialnet.unirioja.es/descarga/articulo/1998029.pdf

Fraser, B. (1988). Types of English discourse markers. Acta Linguistica Hungarica, 38(1-4), 19-33. Retrieved from https://www.jstor.org/stable/44362602

Fraser, B. (2009). An Account of Discourse Markers. International Review of Pragmatics, 1(2), 293320. https://doi.org/10.1163/187730909X1253804 5489818.

Goffman, E. (1981). Forms of talk. University of Pennsylvania Press.

Harmer, J. (2007). The practice of English Language Teaching. Fourth edition. Pearson Education Limited. England.

Hasebe, Y. (2015) Design and Implementation of an Online Corpus of Presentation Transcripts of TED Talks. Procedia: Social and Behavioral Sciences 198(24), 174-182. Retrieved from https://yohasebe.com/tcse/

Heeman, P. A., Byron, D., \& Allen, J. F. (1998). Identifying discourse markers in spoken dialog. Discourse, 58298(6163), 8278. Retrieved from http://www.aaai.org/ 
Howe, M. (1991). Collaboration on topic change in conversation. doi: https://doi.org/10.17161/KWPL.1808.421

Hyland, K. (1999). Disciplinary discourses: Writer stance in research articles. Writing: Texts, processes and practices, 99121.

Johnson, A., (2002). So . . ??: pragmatic implications of so-prefaced questions in formal police interviews. In: Cotterill, J. (Ed.), Language in the Legal Process. Palgrave Macmillan, New York, 91-110. Retrieved from https://doi.org/10.1057/9780230522770_6

MacDonald, M.; Richard, B., \& White, G. (2000). The real thing?: authenticity and academic listening. English for Specific Purposes (19),253-267. Retrieved from https://doi.org/10.1016/S0889-4906(98)00028-3

Moll, T. M. (2000). EFL content lectures: a discourse analysis of an interactive and a non-interactive style. Departamento de Filología inglesa, Universidad de Alicante.

Morell, T. (2004). Interactive lecture discourse for university EFL students. English for specific purposes, 23(3), 325-338. Retrieved from https://doi.org/10.1016/S0889-4906(03)00029-2

Mullany, L. \& Stockwell, P. (2010). Introducing English language: A Resource book for students. Routledge.

Northcott, J. (2001). Towards an ethnography of the MBA classroom a consideration of the role of interactive lecturing styles within the context of one MBA programme. English for Specific Purposes,20, 15-37. Retrieved from https://doi.org/10.1016/S0889-4906(99)00016-2

Purver, M. (2011). Topic segmentation. In: Spoken Language Understanding: Systems for Extracting Semantic Information from Speech, 291-317. Retrieved from https://onlinelibrary.wiley.com/ doi/abs/10.1002/9781119992691

Ranger, G. (2018). Discourse markers: An enunciative approach. Springer.

Rido, A. (2015). The use of discourse markers as an interactive feature in science lecture discourse in L2 setting. TEFLIN Journal, 21(1). Retrieved from http://dx.doi.org/10.15639/ teflinjournal.v21i1/90-106

Rowling, J. K. \& Mariano, S. (2002). A study of the translation of discourse markers in Italian in Harry Potter and the Philosopher's stone. Doi: 10.1.1.567.7341

Sadeghi, B. \& Heidaryan, H. (2012). The effect of teaching pragmatic discourse markers on EFL learners' listening comprehension. English Linguistics Research, 1(2), 165-176. Retrieved from https://doi.org/10.5430/ELR.V1N2P165

Schiffrin, D., 1987. Discourse markers. Cambridge: Cambridge University Press.

Schiffrin, D., Tannen, D., \& Hamilton, H. (2008). The Handbook of Discourse Analysis. Blackwell Publishing.

Tsai, T. J. (2015). Are You TED Talk material? Comparing prosody in professors and TED speakers. In Sixteenth Annual Conference of the International Speech Communication Association.Retrieved from http://www.icsi.berkeley.edu/pubs/speech/tedmaterial15.pdf

Uicheng, K. \& Crabtree, M. (2018). Macro Discourse Markers in Ted Talks: How Ideas Are Signaled to Listeners. PASAA: Journal of Language Teaching and Learning in Thailand, 55, 1-3.

Young, L. (1994). University Lectures-Macro Structures and Micro-Features. Academic Listening: Research Perspectives, 159-176. Retrieved from https://books.google.com.tr/ 